\title{
Gagasan Madrasah al-Zahra': Pemikiran Said Nursi dalam Pendidikan
}

\author{
Mohd Nasir Ayub ${ }^{*}$, Surita Hartini Mat Hassan², Mohd Asmadi Yakob ${ }^{3}$ \\ ${ }^{1}$ Akademi Pengajian Islam Kontemporari \\ Universiti Teknologi MARA Kedah, Kampus Merbok, Kedah, Malaysia \\ ${ }^{2}$ Akademi Pengajian Islam Kontemporari \\ Universiti Teknologi MARA Pahang, kampus Raub, Pahang, Malaysia \\ ${ }^{3}$ Akademi Pengajian Islam Kontemporari \\ Universiti Teknologi MARA, 40450 Shah Alam, Selangor, Malaysia \\ *Pengarang Penghubung \\ mnasir251@uitm.edu.my
}

Received: 11 June 2020

Accepted: 27 June 2020

Online First:

\begin{abstract}
ABSTRAK
Aspek Pendidikan amat ditekankan dalam ajaran Islam. Pendidikan yang berkualiti dan menepati kaca mata Islam akan membentuk sahsiah Muslim yang beriman serta cemerlang dunia dan akhirat. Dalam konteks yang lebih menyeluruh, penubuhan universiti sebagai medan ilmu yang lebih bersistematik telah lama dipraktikkan di negara umat Islam, khususnya dengan kewujudan Universiti Al-Azhar yang merupakan universiti tertua di dunia. Namun, apakah penubuhan universiti-universiti di negara umat Islam kini memenuhi keperluan umat Islam itu sendiri sekaligus menepati ciri-ciri ketamadunan Islam. Artikel ini berhasrat mencungkil idea-idea pendidikan seorang pemikir Islam di akhir pemerintahan kerajaan Turki Uthmani, iaitu Syeikh Badiuzzaman Said Nursi yang dianggap tokoh yang telah menemukan ilmu agama dan ilmu sains dalam kerangka yang satu berdasarkan model Madrasah al-Zahra'. Kajian ini adalah kajian perpustakaan dan analisisnya pula berdasarkan kerangka analisis dokumen. Kajian ini mendapati bahawa idea penubuhan Universiti Islam Madrasah al-Zahra'oleh Syeikh Badiuzzaman Said Nursi amat selari dengan tuntutan
\end{abstract}

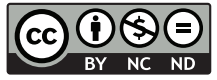


agama, memenuhi keperluan umat Islam serta mengembalikan kekuatan umat Islam dalam mendepani penjajahan kuasa Barat pada ketika itu.

Kata kunci: Madrasah al-Zahra', Said Nursi, Universiti Islam, Kerajaan Turki Uthmani

\title{
The Idea of Madrasah al-Zahra: Said Nursi's Educational Thought
}

\begin{abstract}
Islamic education has been strongly emphasized in Muslim communities. The quality of education and adherence to the Islamic worldview will shape Muslim personalities towards the true meaning of excellence in this world and the hereafter. In the broader context of the establishment of the university as a more systematic field of knowledge has long been practiced in Muslim countries, in particular with the existence of Al-Azhar University, which is the oldest university in the world. However, whether the establishment of a university in a Muslim country now fulfill the needs of the Muslims themselves, while still meeting the characteristics of Islamic civilization. This paper aims to analyze the idea of education of an Islamic thinker at the end of the Ottoman Turkish government, namely Sheikh Badiuzzaman Said Nursi who is considered a figure who tried to integrate the religious and scientific knowledge in a single framework based on Madrasah al Zahra's model. This study is adopted a library research and its analysis is based on a content analysis framework. The study found that the idea of establishing Madrasah al Zahra Islamic University by Sheikh Badiuzzaman Said Nursi was in line with religious demands, to cater the needs of Muslims and restoring the strength of Muslims in leading the occupation of Western powers at that time.
\end{abstract}

Keywords: Madrasah al-Zahra', Said Nursi, Islamic University, Ottoman Turkish Government 


\section{PENDAHULUAN}

Pembangunan sahsiah dan moral umat Islam menjadi agenda utama masyarakat Islam seluruh dunia. Negara Islam masing-masing berkongsi idea untuk mencari penyelesaian terhadap permasalahan yang dihadapi dalam sistem pendidikan negara-negara umat Islam. Terdapat banyak kajian, penyelidikan, seminar, konferensi, penulisan dan sebagainya dibuat bagi merumus permasalahan yang dihadapi seterusnya mencari jalan penyelesaian terhadap sistem pendidikan negara masing-masing dalam kerangka penyelesaian yang sebenar. Terdapat juga negara Islam dengan sewenangnya mengambil sistem pendidikan Barat untuk menyelesaikan masalah sosial yang membelenggu mereka.

Akibat daripada pelaksanaan sistem pendidikan yang tidak menepati kehendak Islam, maka ia menjauhkan umat Islam daripada agamanya sekaligus telah menghakis asas-asas akidah Islam yang tertanam selama kini. Ditambah pula dengan lambakan ideologi peninggalan penjajah Barat menambahkan lagi kecelaruan pemikiran umat Islam. Fahaman Sekularisme, Liberalisme, Sosialisme, Marxisme dan pelbagai lagi ismeisme telah berakar dan meresap masuk ke dalam sistem kehidupan umat Islam sehinggakan sukar untuk dibuang lagi.

\section{METODOLOGI KAJIAN}

Kajian ini adalah kajian kepustakaan. Kajian ini menggunakan kaedah kualitatif bagi mengkaji pemikiran Said Nursi khususnya dalam bidang pendidikan. Sumber utama kajian ini berdasarkan idea asal Said Nursi dalam tafsir Risalah al-Nur. Manakala sumber kedua diperolehi melalui penelitian terhadap kajian-kajian lepas seperti tesis, buku, jurnal, artikel serta bahan-bahan yang berkaitan. Data-data yang diperolehi telah dianalisis menggunakan kerangka analisis kandungan. Dapatan dan analisa yang terkandung dalam penulisan ini boleh dijadikan sebagai salah satu sumbangan akademik dan rujukan dalam membangunkan sistem pendidikan umat Islam seluruhnya. 


\section{BIOGRAFI BADIUZZAMAN SAID NURSI}

Said Nursi dilahirkan pada tahun 1877 M di perkampungan Nurs yang berada di wilayah Bitlis iaitu satu wilayah yang terletak di Timur Turki (Ian S. Markham and Suendam Birinci, 2011; Sarwat Saulat, 1981). Nursi adalah gelaran kepada Said Nursi yang mengambil nama sempena nama kampungnya Nurs. Manakala nama sebenarnya ialah Said. (Sukran Wahide, 1992).

Nursi dibesarkan dalam sebuah keluarga berbangsa Kurdis yang hidup dengan penuh kesederhanan dan kasih sayang. Ayahnya bernama Mirza bin Ali bin Khidir bin Mirza Khalid bin Mirza Rasyad (Muhammad Zahid al-Mullarzkirdi, 1983) berkerja sebagai petani dan kuat berpegang dengan amalan sufi manakala ibunya bernama Nuriyyah binti Mulla Tahir merupakan wanita yang taat kepada perintah Allah. Asuhan yang begitu teliti oleh Mirza dan Nuriyyah telah mempengaruhi pembentukan fizikal dan mental Nursi. Kekuatan akal Nursi terserlah apabila mampu menimbulkan persoalan-persoalan yang hanya difikirkan oleh mereka dalam peringkat dewasa sahaja. Nursi cuba mendapatkan jawapan bagi persoalan yang menarik perhatiannya. Pada suatu malam, Nursi pernah menanyakan kepada ibunya tentang kejadian gerhana bulan, maka ibunya pun menjawab pertanyaan tersebut. Akhirnya jawapan sebenar tentang gerhana itu diperolehi selang beberapa tahun ketika beliau mendalami ilmu astronomi (S.Vahide). Nursi juga berminat mengetahui tentang kehidupan dan kematian, sumbangan ulama kepada masyarakat, menghadiri siri-siri perdebatan serta perbincangan ilmiah yang di adakan di rumah ayahnya (Mohamad Zaidin Mat, 2001). Kitab al-Syu'a 'at menggambarkan keintelektualan Nursi seperti yang dinukilkan oleh Ihsan Qasim al-Salihi (2003).

"Ketika aku masih kecil, aku berimaginasi : Manakah anggapan yang lebih baik antara dua masalah? Apakah hidup bahagia selama seribu-ribu tahun dalam kemewahan dunia dan berkuasa namun berakhir dengan ketiadaan atau kehidupan yang abadi namun ditempuhi dengan penuh derita? Kemudian aku melihat imaginasiku lebih cenderung memilih yang kedua daripada yang pertama dengan menyatakan: Aku tidak inginkan 
ketiadaan, bahkan aku menginginkan keabadian walaupun dalam kebinasaan".

Karakter yang dibentuk sejak beliau kecil lagi sehinggalah dewasa akhirnya membuahkan sifat-sifat murni sebagai seorang remaja Islam sejati. Kekuatan inilah yang digunakan oleh Nursi dalam mengasah bakatnya untuk terus menimba ilmu agama sebanyak mungkin di timur Turki. Manakala penguasaan Nursi dalam bidang sains moden amat terserlah apabila beliau berpeluang menelaah kitab tersebut semasa berada di perpustakaan persendirian Tahir Pasha, Gebenor Van pada ketika itu. Nursi memanfaatkan sepenuhnya peluang tersebut untuk mendalami ilmu sejarah, geografi, matematik, geologi, fizik, kimia, astronomi dan juga falsafah (S. Vahide). Beliau juga berjaya menghasilkan beberapa buah buku dalam disiplin ilmu tersebut.

Melihat kepada keupayaan Nursi yang menguasai pelbagai disiplin ilmu termasuklah dapat mengadunkan ilmu agama dan ilmu sains moden dalam metodologi pengajaran yang baik serta sesi perdebatannya yang mengkagumkan, maka ulama-ulama dan masyarakat pada masa itu mengiktiraf keilmuan Nursi dan menggelarkan beliau sebagai Bediuzzaman Said Nursi yang bermaksud Said Nursi Bintang Zaman atau The Wonder of The Age (Hasan Horkuc, 2004). Kredibiliti Nursi dalam kesarjanaan Islam amat terserlah apabila menjadi pakar rujuk oleh ulama-ulama pada ketika itu. Beliau telah dilantik menganggotai Darul Hikmah Islamiah iaitu sebuah organisasi di bawah kerajaan Uthmani yang dianggotai oleh sekumpulan ulama terpilih seluruh wilayah Uthmani. Penubuhan organisasi ini bertujuan menjelaskan setiap persoalan yang ditimbulkan oleh rakyat serta menjawab serangan musuh dan tohmahan (Mohd Nasir Ayub, 2015).

Pada hari rabu 5 Ramadhan 1379H bersamaan 23 Mac 1960 diusia 83 tahun, Nursi kembali ke Rahmatullah menemui Rabb al-Jalil (I.S. Markham, 2011). Berita kematian Nursi disiarkan di dalam akhbar-akhbar di Istanbul dan Ankara. Beribu-ribu orang dari seluruh Turki datang menziarahi Nursi dan menghadiahkan solat jenazah kepada tokoh ulama yang ikhlas memperjuangkan Islam. Dalam Sirah Zatiyah telah menceritakan bagaimana pasar-pasar di bandar Urfa di tutup serta orang ramai keluar ke jalan-jalan dan juga memenuhi masjid. Akhirnya jenazah selamat dikebumikan di perkuburan Ulu Jami' (Masjid Ulu) pada khamis, 24 Mac selepas solat asar (Nursi, 2011) 
Journal of Contemporary Islamic Studies

\section{Kelemahan Sistem Pendidikan Umat Islam}

Sistem pendidikan secara formal dan tidak formal telah lama bertapak dan sebati dalam kehidupan umat Islam. Sistem pendidikan umat Islam kini menampakkan kemajuannya dalam pelbagai sudut, namun ia masih dalam aliran perubahan kepada yang lebih baik. A.L Tibawi (1972) turut membincangkan perkembangan pendidikan kebanyakan negara-negara umat Islam yang semakin terbuka selepas Perang Dunia II, khususnya setelah mendapat kemerdekaan daripada kuasa penjajah. Kesan peninggalan penjajah menyebabkan berlakunya beberapa kecelaruan dalam pemikiran pendidikan umat Islam. Untuk mengatasi masalah itu, cendekiawan Muslim seluruh dunia hadir ke kota suci Mekah dalam Persidangan Sedunia Pertama Tentang Pendidikan Islam tahun 1977 dengan tujuan mencari penyelesaian terhadap kecelaruan yang berlaku. Akhirnya sebuah buku yang bertajuk Crisis in Muslim Education tahun 1979 berjaya diterbitkan di Universiti Raja Abdul Aziz, Jeddah (Syed Sajjad Husain \& Syed Ali Ashraf,1989). Reaksi terhadap permasalahan pendidikan umat Islam bukan sahaja bermula pada persidangan tersebut, bahkan sepuluh tahun sebelum itu telah pun dibincangkan oleh para ilmuwan Islam seperti Abu Hasan 'Ali al-Nadwi (1969) dalam buku beliau Nahwu al-Tarbiyyah al-Islamiyyah al-Hurrah sebagai usaha membebaskan sistem pendidikan umat Islam daripada dimasuki anasir luar dan ideologi barat serta menyediakan jalan penyelesaiannya. Manakala menurut penelitian al-Faruqi (1982) dan Abdul Halim Ramli (2007), teras kepada permasalahan yang berlaku berpunca daripada kelemahan dalam pendidikan umat Islam itu sendiri.

Jelas bahawa terdapat kelompangan yang ketara dalam sistem pendidikan umat Islam kini seperti ketidakfahaman terhadap falsafah pendidikan Islam, metodologi pengajaran, matlamat penubuhan Universiti Islam dan sebagainya. Tindakan segera perlu dilakukan bagi memastikan bahawa kelompangan yang wujud dalam sistem pendidikan umat Islam perlu terus diperbaiki lagi. Anjakan paradigma baharu perlu dilakukan bagi memenuhi tuntutan kecemerlangan ummah dalam kontek pendidikan umat Islam yang menyeluruh. 


\section{Pendidikan Islam pada Akhir Kerajaan Turki Uthmani}

Pada zaman kegemilangan kerajaan Uthmani, khususnya semasa pemerintahan Sultan Muhammad al-Fatih, pengajian agama dan sains moden diajarkan di sekolah-sekolah dengan amat cemerlang sekali. Dalam kitab Hadiqah al-Azhar wa al-Rayahin mencatatkan beberapa tokoh kerajaan Uthman yang cintakan ilmu dan membantu membangunkan pendidikan dan keintelektualan khilafah Uthman ialah seperti Sultan Bayazid II, Sultan Sulaiman bin Sultan Salim I, Sultan Murad III bin Sultan Salim II, Sultan Ahmad I bin Sultan Muhammad III serta Sultan Mustafa II bin Sultan Muhammad IV (Abdul-Ramae Sulong, 2013). Namun begitu perkembangan ini semakin malap setelah berakhirnya Tanzimat (iaitu proses pembaharuan politik oleh Sultan Abdul Majid pada 1839), ia menjadi perlahan khususnya pada zaman pemerintahan Parti Kesatuan). Berdasarkan mengamatan Justin (1997), walaupun bidang pendidikan bergerak secara perlahan namun dibandingkan dalam bidang ekonomi, ia jauh lebih berjaya.

Pada zaman Tanzimat dan era kejatuhan Uthmani, beberapa tokoh bertanggungjawab terhadap kemunduran sistem pendidikan kerajaan Uthmani seperti Mustafa Rasyid Pasha, Fuad Pasha yang bertanggungjawab membuang pelajaran sains di madrasah. Manakala semasa Mithat Pasha dan Talat Pasha yang bertanggungjawab mengurangkan mata pelajaran agama di madrasah. Bahkan Mithat Pasha telah merancang untuk menyerang Islam dan al-Quran melalui beberapa perancangan jahat. (Waqf Ikhlas Publications, 1986).

Proses Tanzimat melihat banyak perubahan berlaku dalam sistem pendidikan Uthmani merekodkan penubuhan Kementerian Pelajaran Umum bagi menyelaras penubuhan sekolah-sekolah sekular. Pendidikan al-Quran peringkat rendah harus disertakan dengan pendidikan sekular peringkat rendah. Maka wujudlah peringkat Rushdiye (4 tahun), I'dadi (3 tahun) dan Sultani. Namun golongan bukan Islam mendominasi sistem pendidikan ini berbanding anak-anak Islam. Penubuhan institusi pendidikan tinggi oleh warga asing makin bertambah. Monroe (1985) mencatatkan kebangkitan kolej-kolej dan Universiti yang dibiayai oleh Barat seperti Kristian Protestan dan Roman Catholic Mission. Gerakan misionari Protestan mempunyai 527 sekolah dengan 23572 orang pelajar. Terdapat juga 45 kolej dengan jumlah 3004 orang pelajar di seluruh kerajaan Uthmani. Mengambil 
contoh Universiti Robert tahun 1863 (sekarang ini Universiti Bosforus atau Bogazici) dan Maktab Protestan Syria tahun 1866 (sekarang ini American University of Beirut). Kedua-duanya institusi tersebut dibina oleh warga Amerika. Dasar keterbukaan ini membuka peluang kepada bukan Islam khususnya orang Kristian untuk memasuki jawatan-jawatan dalam perkhidmatan awam kerajaan Uthmani.

Usaha pertama membangunkan institusi pendidikan tinggi kerajaan Uthmani bernama Darulfunun iaitu semasa pemerintahan Sultan Abdul Majid (1839-1861), di era Tanzimat. Namun, Darulfunun dalam proses awal penawarannya tahun 1846 kurang berjaya dan tawaran universiti yang kurang teratur tahun 1860-an. Universiti Darulfunun dibuka semula tahun 1870-1871 dan kemudiannya tahun 1900 (Lois A. Aroian \& Richard P. Mitchell, 1991). Tahun 1900, mahasiswa baharu mengalami zaman pemodenan sistem universiti dengan mengambil model universiti di Amerika dan Eropah termasuk penubuhan fakulti sains dan kedoktoran. Setelah menjadi Republik Turki, Darulfunun menjadi Universiti Istanbul dan Muhendishane menjadi Universiti Teknikal Istanbul yang merupakan institusi pendidikan tinggi yang pertama di era Turki moden.(John Freely, t.t)

Fazlur Rahman (1985) ada merekodkan, pada masa pemerintahan Sultan Abdul Hamid II terdapat rancangan pendidikan yang menyeluruh. Perdana Menteri mengusulkan untuk didirikan setiap wilayah dalam kerajaan Uthmani sebuah universiti dan lembaga ilmu teknologi tinggi dan menjadikan semua lembaga tinggi ilmu keagamaan (Islam, Kristian dan lain-lain), dengan menubuhkan fakulti teologi di universiti-universiti bagi pemeluk masing-masing, namun rancangan ini gagal. Bahkan pendidikan sekular lebih mendahului. Berdasarkan penelitian Rashid Redha, kegagalan penstrukturan institusi pendidikan di Turki dan Mesir disebabkan tiada komitmen dan perancangan yang menyeluruh. Kalau pun ada sistem pendidikan formal yang ditubuhkan oleh pemerintah, namun ia hanya memenuhi keperluan pemerintah dalam menguruskan pemerintahan negara juga kepentingan sesetengah pemimpin yang korup (Mappangaro, 1989).

Lanjutan dari itu, tahun 1909, Madrasah Sultan Muhammad al-Fatih dihidupkan bagi meraikan golongan Barat (Westernis) dan Islamis agar dilaksanakan kurikulum yang sintesis dan diperbaharui. Lembaga ini mempunyai empat fakulti iaitu fakulti ilmu-ilmu agama (mata pelajaran 
tradisional dan juga etika), fakulti ilmu-ilmu hikmat (ilmu filsafat, matematik dan ilmu-ilmu alam), fakulti ilmu sejarah (termasuk riwayat hidup Nabi s.a.w.) serta fakulti bahasa (Arab, Turki dan Parsi). Beberapa tahun berikutnya tanggungjawab membangunkan pendidikan Islam daripada Syeikh Islam diserahkan kepada Kementerian Pendidikan. Apabila sistem pendidikan Islam telah diletakkan di bawah kelolaan kementerian pendidikan umum dan bukan lagi di bawah Syeikh Islam, maka dualisme pendidikan menjadi sebahagian daripada agenda besar negara dan telah diterapkan dalam sistem pendidikan kerajaan Turki moden. Hasilnya, berlakulah dualisme dalam pendidikan dan ilmu sains terus di perhebatkan berbanding ilmu agama yang semakin terpinggir.

Hal ini terbukti apabila Fazlur Rahman (1985) merekodkan pada tahun 1916, Mustafa Kamal mengusulkan Undang-Undang Penyatuan Pendidikan yang menghapuskan sistem pendidikan agama yang menjadi tunggak dan tradisi sistem pendidikan yang sekian lama dipraktikkan dalam kerajaan Uthmaniyah. Madrasah Khur Khur yang dikelolakan oleh Nursi sebagai peringkat asas atau tapak permulaan (al-ibtida'iyyah) kepada Madrasah al-Zahra' juga mengalami nasib yang sama diarah untuk menamatkan operasinya oleh pemerintah Turki (Nursi, 2011).

Walaupun undang-undang ini ditentang oleh majoriti masyarakat Turki, namun Mustafa tetap melaksanakannya demi menjadikan Turki maju seperti Barat. Situasi ini sebenarnya menjauhkan lagi umat Islam dengan agama yang dianuti. Apabila membelakangi syariat Allah, maka berlaku kecelaruan dalam tindakan dan perancangan. Amaran Nursi (2011) dalam Sirah Zatiyah, ilmu yang sepatutnya menjadi penyelesai itu telah menjadi wasilah untuk melakukan kezaliman. Maka, berlakulah pentadbir yang dilantik bukan di kalangan ahlinya, begitu juga di sekolah-sekolah agama. Jalan penyelesaiannya ialah dengan melaksanakan pengkhususan sekolahsekolah dan juga universiti mengikut kecenderungannya secara fitrah, menepati urusan maknawi untuk mencapai hikmah yang azali (hikmah Allah).

Menurut pengamatan Nursi lagi, jalan untuk mengembalikan kemajuan umat Islam ialah dengan kembali kepada agama Islam dan bukannya menuruti kemajuan Barat secara melulu. Nursi meyakini bahawa tindakan yang perlu ialah dengan membuka pengajian ilmu-ilmu sains moden 
sama ada memasukkan ilmu moden ini ke dalam sekolah-sekolah agama, seterusnya dengan idea penubuhan universiti Islam yang mengajarkan ilmuilmu sains tabii, fizik, astronomi dan sebagainya di samping pengajaran ilmu-ilmu agama dan pengajian al-Quran.

Keyakinan Nursi bersandarkan kepada amalan di sekolah Khur Khur kelolaannya sendiri di Van. Sukran Vahide (2003) mencatatkan kejayaan amalan ini apabila berjaya menolak tanggapan negatif masyarakat Turki bahawa ilmu agama dan sains tidak boleh bersatu adalah tidak benar sama sekali. Sedikit demi sedikit usaha beliau menampakkan hasil yang positif dalam mengubah minda muridnya. Mereka mulai sedar bahawa kedua ilmu itu memberi manfaat kepada umat Islam seluruhnya. Kejayaan di sekolah Khur Khur ini menyebabkan bercambahnya madrasah-madrasah di timur Turki yang menerapkan ilmu agama dan ilmu moden kepada pelajar-pelajar dan mereka berjaya menguasai kedua-duanya. Alangkah baiknya sekiranya cara ini dilaksanakan di sekolah-sekolah seluruh Turki (Abdul Latip Talib, 2012). Menurut Faridah Sairi (2012), Nursi berjaya mengubah sistem pembelajaran pada masa itu yang bersifat sekular. Sebelum itu, tiada sekolah, madrasah atau institusi pengajian tinggi di Turki yang menggabungkan ilmu tradisional agama dengan ilmu sains moden. Usaha Nursi (2011) untuk melonjakkan lagi prestasi sekolah Khur Khur terhalang apabila wujud peraturan dan polisi kerajaan bagi menutup semua jenis sekolah agama di Turki pada masa itu. Manakala menurut al-Dabbagh (t.t) sebelum undangundang penyatuan pendidikan oleh Mustafa Kamal, Nursi juga telah ke Istanbul untuk membincangkan gagasan pendidikan ini, namun usaha dan sensitiviti Nursi tidak juga dipedulikan oleh pihak istana Yildiz. Hal ini sebenarnya mempercepatkan lagi cita-cita Gladstone suatu ketika dulu yang ingin menjauhkan umat Islam dengan al-Quran (Abdul Latip Talib, 2012).

\section{Nursi Dan Gagasan Madrasah Al-Zahra'}

Madrasah al-Zahra' merupakan gagasan untuk membangunkan sistem pendidikan umat Islam yang lebih menyeluruh khususnya di timur Turki. Nursi melihat sistem pendidikan yang betul adalah penyelesaian terhadap kemunduran umat Islam di akhir kejatuhan kerajaan Uthmani pada masa itu. Rentetan daripada itu, Nursi (2011) menyebut "menjadi permasalahan besar dalam sistem pendidikan umat Islam apabila ilmu sains teknologi moden diangkat secara melampau dan berlebih lebihan sehingga mengabaikan ilmu agama. Pada ketika itu ilmu agama sebagai pengikut sahaja". 
Apabila umat Islam meninggalkan ajaran al-Quran dan terpesona dengan idea Barat, maka mudah bagi musuh-musuh Islam menguasai pemikiran ummah dan bersedia untuk dijajah. Satu peristiwa yang amat terkesan kepada Nursi dan seluruh umat Islam apabila Gladstone (Menteri Tanah Jajahan Britain) di dalam Dewan Rakyatnya secara angkuh menyatakan (Nursi, 2011; Maryam Jameelah, 1983):

"Selama mana al-Quran ini masih berada di tangan orangorang Islam (sambil menunjukkan al-Quran ditangannya), maka (selama itulah) kita tidak akan dapat menguasai mereka dengan sebenar-benarnya. Maka hendaklah kita longgarkan ikatan alQuran dari pegangannya".

Berpijak daripada penghinaan Gladstone kepada al-Quran dan umat Islam seluruhnya, maka Nursi bercita-cita mengembalikan nur al-Quran dan meletakkan umat Islam di kedudukan yang sewajarnya. Bermulalah usaha beliau memperjuangkan universiti Islam di timur Turki yang diberi nama Madrasah al-Zahra' sebagai usaha mempertingkatkan lagi mutu pendidikan umat Islam dalam mengharungi arus modenisasi dan teknologi Barat. Nursi (2011) merumuskan terdapat dua cara untuk mengekalkan kesejahteraan dan keamanan di timur Turki iaitu, pertama, menulis kitab Rasail al-Nur. Kedua, menubuhkan Universiti Madrasah al-Zahra yang berperanan mengukuhkan keimanan dan ukhuwah umat Islam, buktinya Nursi menulis dalam suasana kezaliman dan kekerasan, kesan di masa akan datang kepada umat Islam dan Eropah dan Amerika, menolak dan mencantas falsafah atheis dan faham Sekularisme Barat. Manakala penubuhan Universiti Madrasah al-Zahra' berperanan sebagai pusat keilmuan di Asia setelah Universiti Al-Azhar di utara Afrika.

Universiti al-Azhar, Mesir menjadi model penubuhan Madrasah al-Zahra' kerana kekuatan dan kehebatan sejarah kerajaan Fatimiyah itu sendiri dan jolokan yang dianugerahkan oleh umat Islam terhadapnya. Menurut John Freely (t.t), zaman kegemilangan kerajaan Fatimiyah di Mesir merupakan kerajaan yang paling kuat dunia Islam. Wilayah Afrika, utara Syria, Hijaz, Sicily dan Kaherah menjadi pusat kebudayaan mengungguli Baghdad. Manakala Philip K. Hitti (2005) menyebutkan bahawa Khalifah al-'Aziz yang bertanggungjawab mengembangkan masjid Al-Azhar menjadi universiti al-Azhar. Sumbangan terbesar Fatimiyah di Mesir ialah 
pembangunan Dar al-Hikmah (Rumah Kebijaksanaan) atau Dar al-'Ilmi (Rumah Ilmu) yang didirikan oleh khalifah al-Hakim pada $1005 \mathrm{M}$. sebagai pusat penyebaran ajaran syiah yang ekstrim. Khalifah al-Hakim menyuntik dana sebanyak 257 dinar dalam usaha membiayai, menyalin pelbagai naskhah, memperbaiki buku dan pemuliharaan umum lainnya. Kurikulum meliputi ilmu-ilmu keislaman, astronomi, dan kedoktoran. Universiti alAzhar dinobatkan sebagai universiti tertua sekali di dunia (Fadzlullah $\mathrm{Hj}$ Shuib, 2005).

'Abd al-Wadud Syalabi (1999) memetik kata-kata Abu al-Kalam Azad (pemimpin Muslim di India) tentang Al-Azhar, "Apabila kiblat kaum Muslimin dalam solat lima waktu di ka'bah, maka kiblat yang lain bagi umat Islam pada setiap masa iaitu Al-Azhar".

Madrasah al-Zahra' merupakan sekolah mengajarkan sains moden dan dalam masa yang sama mengajarkan ilmu-ilmu Islam. Pemilihan tempat disebabkan Asia lebih besar daripada Afrika yang mewakili bangsa Arab, India, Iran, Caucasus, Turki dan Kurdis serta mengharapkan agar ukhuwah mereka lebih terjamin (Nursi, 2011). Bertepatan dengan firman Allah SWT yang bermaksud:

"Sebenarnya orang-orang yang beriman itu adalah bersaudara, maka damaikanlah di antara dua saudara kamu (yang bertelagah) itu; dan bertaqwalah kepada Allah supaya kamu beroleh rahmat".

(surah al-Hujurat: 10)

Dalam majalah The Pen (2012) menyebutkan keperluan mendesak penubuhan Madrasah al-Zahra' serta kepentingannya yang amat diperlukan. Madrasah al-Zahra' menghimpunkan tiga jenis aliran yang sedia ada (aliran sains moden, agama dan tariqat) menjadi satu:

'We need the Madrasatu'z-Zahra Project of Bediuzzaman much more now than at any time in the past in order to establish Islamic unity and develop our countries and the Islamic world, and to nurture peace in the global sphere. The solution to this need should not be postponed. The Islamic countries and the non-government organizations should lay claim to this project, 
which brings the modern school, the madrasa and the Sufi lodge together to develop the minds and hearts of the coming generations both materially and spiritually".

Inilah yang cuba dibangunkan oleh Nursi dalam pembaharuan pendidikan di Madarsah al-Zahra'. 'Abd al-'Aziz al-Barghuth (2006) mencatatkan bahawa inspirasi Nursi bukan sekadar untuk menyampaikan maklumat, ilmu dan pemikiran, atau untuk mendidik beberapa amalan yang zahir, atau untuk mengubati kecelaruan akidah dan akhlak umat Islam, tetapi pendidikan yang lebih memenuhi syarak sifatnya bagi membina insan yang bertamadun dan kehidupan masyarakat yang seimbang. Dengan itu, hakikat ketinggian universiti itu akan terserlah apabila apabila semua ahlinya berpegang dengan budaya ilmu. Kecemerlangan akademik di sesebuah universiti tidak akan tercapai jika tidak diasaskan kepada pembinaan budaya ilmu yang bersepadu, jitu dan kudus. (Zaini Ujang, 2012).

Nursi berjuang untuk menubuhkan Madrasah al-Zahra' di timur Turki ini menjalani masa yang agak panjang bermula pada zaman Khalifah Uthmani terakhir Sultan Abdul Hamid II, seterusnya Presiden Mustafa Kamal al-Tarturk daripada Parti Republik Rakyat sehinggalah Presiden Jalal Bayar daripada Parti Demokratik Rakyat. Nursi meyakini bahawa jalan penyelesaian terhadap segala permasalahan umat Islam seluruhnya adalah kembali kepada syariat dan membangunkan ilmu pengetahuan yang seimbang.

Dalam Sirah Zatiyah ada merekodkan secara terperinci, Sultan Muhammad Rasyad (1814-1918) meluluskan sebanyak 20 ribu lira bagi membina Madrasah al-Zahra' (Wan Jaffree Wan Sulaiman,1987). Ketika Nursi kembali dari menjadi tawanan Perang Dunia I, Majlis Perwakilan meluluskan 150 ribu lira untuk tujuan yang sama. Begitulah keperluan yang teramat sangat membina universiti di wilayah Van dengan nama Madrasah al-Zahra' yang mengambil sempena al-Azhar al-Syarif, sehinggakan beliau sendiri meletakkan batu asas penubuhannya. Ia berpusat di Bitlis dan mempunyai cawangannya di Van dan Diyarbakir. Tetapi usaha itu tidak kesampaian apabila tercetusnya Perang Dunia I, yang menyaksikan Nursi mengetuai pasukan bantuan (firaq al-Ansar) bersama dengan muridmuridnya melawan tentera Rusia di Bitlis. Setelah 6 tahun berikutnya, Nursi ke Ankara dengan maksud yang sama. Sepakat perwakilan 163 orang 
daripada 200 orang meluluskan pembinaan Madrasah al-Zahra' dengan peruntukan pendahuluan sebanyak 15 ribu lira. Namun hasrat sekali lagi tidak tercapai setelah posisi pergantungan sekolah-sekolah agama seluruh Turki oleh pemerintah (Nursi, 2011). Menjelang tahun 1950, setelah 15 tahun berlalu, Presiden Jalal Bayar dan Menteri Pendidikan, Taufiq Elri sebagai memenuhi cita-cita Madrasah al-Zahra' di Van dengan nama Universiti Timur (Jami'ah al-Syarq) dengan peruntukan dana sebanyak 60 juta lira bagi kos operasinya. Usaha Nursi selama 40 tahun sebelumnya itu tertunai dengan izin Allah (Nursi, 2011).

Dari segi faedah dan kepentingan kewujudan Madrasah al-Zahra' amat banyak. Paling penting, membuka minda umat Islam dan para ulama yang sekian lama tertutup bahawa untuk mencapai kebahagiaan di dunia ialah dengan menguasai ilmu agama dan ilmu sains moden serta kepentingan memahaminya (Nursi, 2011). Memandangkan wilayah timur Turki dianggap mundur dalam arus pendidikan negara berbanding wilayahwilayah lain, bahkan ramai yang masih tidak mengetahui bahasa Turki. Hanya sekolah agama menjadi pilihan mereka untuk mendapatkan ilmu. Maka wujud elemen ketaksuban, tersebarnya syubhah, perpecahan puak dan menyanjung Barat kerana kejahilan mereka. Nursi menyebut, perlunya usaha menghidupkan sekolah di wilayah Kurdis, menghidupkan ilmu dan membina kekuatan antara mereka yang semakin lemah akibat perselisihan dalaman terhadap kerajaan, begitu juga untuk membina kekuatan dalam menghadapi musuh dari luar (Nursi, 2011). Nursi menyatakan,“..madrasah ini menjadi batu asas pembebasan kesejahteraan di Timur Tengah, benteng yang kukuh, menghasilkan faedah menyeluruh bagi membaiki negara dan umat ini dengan izin Allah." Ilmu-ilmu Islam menjadi asas di universiti ini kerana kekuatan dari luar berupa ateis telah memadamkan semangat (umat Islam) dan tidak ada yang dapat menghentikannya kecuali dengan menyediakan kekuatan semangat yang hebat juga (yakni menegakkan syariat). Di samping menganjurkan kesejahteraan antarabangsa di antara umat Islam di wilayah Timur yang hampir 400 juta orang dan kelompok dunia Kristian. Kesejahteraan antarabangsa itu sebenarnya berdasarkan dua natijah yang telus dan tinggi iaitu mempamerkan Islam dan menyebarkan hakikat al-Quran kepada semua (Nursi, 2011).

Nursi menyimpulkan idea Madrasah al-Zahra' kepada tiga kepentingan umum iaitu: Pertama; menjamin kesejahteraan ulama bangsa Kurdis dan 
bangsa Turki di masa akan datang. Kedua, menyebarkan ilmu pengetahuan di kawasan Kurdistan dengan cara mendirikan madrasah-madrasah. Ketiga, menzahirkan kebaikan dalam proses perlembagaan (al-Masyrutiyyah) dan kebebasan (al-Hurriyyah) oleh kerajaan dan mengambil faedah dari proses keduanya (Nursi, 2011; Zaidin Mat, 2003). Kepentingan secara terperinci dijelaskan seperti berikut:

1. Menyatukan(tauhid) sekolah agama dan melaksanakan penambahbaikan (al-islah).

2. Membebaskan Islam dari cerita-cerita mitos, Israiliyat dan taksub kebencian.

3. Membuka pintu menyebarkan kebaikan perlembagaan negara (alMasyrutiyah).

4. Membuka jalan mengalirnya ilmu alam moden ke sekolah agama dan penerimaan sekolah agama terhadap ilmu sains moden. Salah faham terbesar ialah - wujud pertentangan antara zahir Islam dan beberapa permasalahan tentang ilmu. Sebab terbesar umat Islam negatif terhadap kesenangan dunia, menghalang orang asing dari mengecapi akhirat, menghalang sinar Islam dan salah faham tentang ilmu, keraguan terhadap sifat Islam serta menyalahi hakikat keilmuan.

5. Mencantumkan membaiki antara sekolah agama (al-diniyyah), sekolah sains (al-hadithah) dan sekolah tarekat (al-takaya). Sekurangkurangnya bersatu dalam mencapai tujuan (al-maqsad). Apabila ia tidak disatukan akan timbul ketaksuban yang melampau yang membawa kepada ifrat dan tafrit. Sama ada dengan menyesatkan mereka atau dari pihak yang lain menjahilkan mereka (Nursi, 2011).

Dalam pada itu, Nursi meletakkan beberapa syarat penubuhan Madrasah al-Zahra' agar segala perancangan yang diatur berjalan dengan lancar. Dalam Sirah Zatiyah, Nursi meletakkan tujuh syarat untuk menubuhkan Madrasah al-Zahra' iaitu:

1. Dinamakan dengan "al-Madrasah" kerana dekat dan hampir dan menepati, sebagai iktibar terhadap hakikat yang terkandung di dalamnya. 
2. Mencampurkan ilmu alam moden dengan ilmu agama dan menjadikan bahasa Arab sebagai bahasa wajib digunakan, bahasa Kurdi diharuskan dan bahasa Turki digalakkan. Sesungguhnya sinaran hati dengan ilmu agama, cahaya akal dengan ilmu moden. Mencampurkan keduanya akan terungkaplah (tajalli) hakikat. Maka akan membentuk semangat pelajar dan meninggikan keduanya. Membezakan keduanya akan melahirkan sikap taksub pada pertama (ilmu agama) dan condong, syubhah kepada kedua (ilmu moden).

3. Pemilihan guru. Sama ada daripada ulama Kurdis yang mahir dalam dua bidang itu yang berada kawasan bangsa Kurdis atau kawasan bangsa Turki, atau mereka yang mengetahui bahasa setempat bagi memupuk minat pelajar.

4. Ia hendaklah dibawa mesyuarat (al-Istisyarah) bagi melihat persiapan orang-orang Kurdis dan penerimaan mereka sebagai mendapatkan impak yang sewajarnya. Berapa banyak pakaian (persekitaran) yang sesuai terhadap sesuatu kaum tetapi buruk bagi orang lain. Begitu juga pengajian bagi anak-anak itu kadang-kadang melalui kekerasan ataupun juga dengan melihat kecenderungan mereka.

5. Melaksanakan kaedah pembahagian kerja "taqsim al-a "mal" sehingga melahirkan pelajar yang mahir dan mendalami dalam satu-satu bidang. Mengikuti dan mentaati undang-undang penyempurnaan diri dan pendakian menuju Allah adalah fardu dan wajib kecuali ketaatan yang tidak memenuhi hak keduanya.

6. Mencari jalan menjamin kemajuan pelajar, teliti dan lengkap sehingga menyamai graduan sekolah tinggi. Bergaul bersama dengan pelajar sekolah tinggi dan kolej-kolej kerajaan. Menjadikan peperiksaan pun sama taraf dengan sekolah umum, tanpa ketinggalan sedikit pun.

7. Membuat kerjasama dengan Kolej Perguruan (Dar al-Mu'allimin) untuk sementara dengan tujuan memfokus kepada sekolah dan proses integrasi, memudahkan penyusunan dan melengkapkan ilmu keduadua bidang agama dan sains. 
Dapat disimpulkan bahawa kesungguhan Nursi membangunkan Madrasah al-Zahra' menunjukkan keperluannya yang mendesak kepada umat Islam serta bagi memastikan keutuhan umat Islam terpelihara. Kejahilan akan menjadikan umat Islam jauh daripada petunjuk Allah dan bersedia menerima gaya hidup Barat yang menyeleweng.

\section{KESIMPULAN}

Kesepaduan ilmu dunia dan ilmu akhirat menjadi asas penubuhan Madrasah al-Zahra'. Nursi melihat kepincangan yang berlaku dalam sistem pendidikan umat Islam rata-rata hanya menekankan ilmu agama dan meminggirkan ilmu sains moden. Manakala satu pihak yang lain, menekankan pengajian ilmu moden dengan mengenepikan pengisian ilmu agama. Di samping sikap umat Islam yang tidak mahu menumpukan ketekunan dalam membangunkan ilmu sains Islam secara menyeluruh. Umat Islam hendaklah membina acuannya tersendiri dalam sistem pendidikan yang lebih holistik. Berdasarkan idea Nursi di abad ke 20, Gagasan Madrasah al-Zahra' adalah contoh model pelaksanaan pendidikan umat Islam yang benar-benar menepati keperluan zaman berdasarkan cabaran dan ancaman terhadap pemikiran ummah. Namun universiti Islam di abad ke 21 ini juga wajar merangka dan mengenalpasti kelompangan yang ada berdasarkan keperluan dan ancaman semasa yang lebih mencabar.

Mendepani sistem universiti umat Islam kini, ianya wajar dilihat dengan lebih menyeluruh dan proses tranformasi ke arah yang lebih baik. Universiti -universiti di negara umat Islam telah pun menerapkan unsur Islami dalam sistem pendidikan universiti mereka, dengan penubuhan fakulti Islam seperti Fakulti Pengajian Islam, Fakulti Ilmu Wahyu dan sebagainya. Namun kelompangannya masih ada, apabila graduan yang dihasilkan itu masih terikat dengan fakulti yang dipelajari dan takut mengaitkannya dengan falsafah ilmu-ilmu Islam. Dalam mendepani abad ke 21 ini, cabaran yang dihadapi yang oleh universiti Islam mungkin berubah. Bukan setakat islamisasi terhadap ilmu sains moden akan tetapi mesti cakna terhadap virus pemikiran terkini seperti pemikiran pasca-modenisme yang menafikan peranan Tuhan dalam kajian ilmu-ilmu sains. 
Justeru itu, kekuatan umat Islam akan terserlah dan digeruni apabila umat Islam berjaya melonjakkan diri dalam aspek keilmuan dengan membina model pendidikan yang sepadu merangkumi penguasaan ilmu agama dan ilmu sains moden. Ilmu keagamaan yang sedia ada hendaklah diperkasakan, manakala ilmu sains hendaklah dikuasai sepenuhnya serta menjadi ilmu yang penting untuk dipelajari dalam sistem pendidikan umat Islam. Penggabungan kedua ilmu ini sebenarnya merancakkan lagi pembangunan umat Islam itu sendiri seterusnya menjadikan sistem pendidikan sebagai penggerak utama kelestarian tamadun ummah.

\section{PENGHARGAAN}

Sebahagian kajian ini adalah daripada penuyelidikan pengajian Doktor Falsafah (2015) di jabatan Falsafah Dan Tamadun, Pusat Pengajian Ilmu Kemanusiaan, Universiti Sains Malaysia, Pulau Pinang. Sekalong penghargaan diucapkan kepada Penyelia, Profesor Madya Dr. Muhammad Azizan Bin Sabjan kerana bimbingan dan tunjuk ajar yang diberikan semasa menyiapkan penuyelidikan ini.

\section{RUJUKAN}

'Abd al-'Aziz Barghouth, 2006. Nahwu Nazariyah Islamiyah fi Tajaddudi al-Hadari, (Ishamat Badiuzzaman al-Nursi), UIAM: Gombak.

'Abd al-Wadud Syalabi, 1999. Al-Azhar ila Aina?!, Kaherah: Dar al-I'tisam.

Abdul Halim Ramli, 2007. Memahami Islamisasi Ilmu Dari Pemikiran Prof. Ismail Ragi Al-Faruqi, Shah Alam: Pusat Penerbitan Universiti (UPENA) UiTM.

Abdul Latip Talib, 2012. Badiuzzaman Said Nursi Pejuang Dan Pemikir Islam, Selangor: PTS Litera Sdn. Bhd..

Abdul- Ramae Sulong, 2013. Pemikiran Turki Uthmaniyah Menurut Syeikh Wan Ahmad bin Muhammad Zain al-Fatani Dalam Bukunya Hadiqah al-Azhar wa al-Rayahin, Universiti Sains Malaysia, (Tesis PhD, tidak diterbitkan). 
Abu Hasan Ali al-Nadwi, 1969. Nahwu al-Tarbiyyah al-Islamiyyah alHurrah,

Adib Ibrahim al-Dabbagh,Sa 'id al-Nursi Rajul al-Iman fi Mihnah al-Kufr wa al-Iman, al-Kuwait: Dar al-Watha'iq, t.t.

Fadzlullah Hj Shuib, 1995. Kecemerlangan Ilmu Dalam Sejarah Dan Tamadun Islam, Kuala Lumpur: Pustaka Warisan.

Faridah Mohd Sairi, 2012. Metode Dakwah Badiuzzaman Said Nursi Dan Pengaruhnya di Turki, Jabatan Dakwah Dan Pembangunan Insan, Akademi Pengajian Islam Universiti Malaya, (Tesis $\mathrm{PhD}$, tidak diterbitkan).

Fazlur Rahman, 1985. Islam dan Modernitas Tentang Tranformasi Intelektual, terj: Ahsin Mohamad, Bandung: Penerbit Pustaka.

Hasan Horkuc,2004. Said Nursi's Ideal for Human Society: Moral and Social Reform in the Risale-i Nur, Durham University, United Kingdom, (Tesis $\mathrm{PhD}$, Tidak diterbitkan).

Hassan Langgulung, 1986. Pengenalan Tamadun Islam Dalam pendidikan, Kuala Lumpur: DBP.

Ian S. Markham \& Suendam Birinci, 2011. An Introduction to Said Nursi Life, Thought and Writing, England: Ashgate Publishing Limited.

Faruqi, Ismail Raji al-, 1988. "Universiti Islam: Masalah Dan Hasrat" dalam Pemikiran Islam Al-Faruqi, Ismail Al-Faruqi dan Lois Lamya' Al-Faruqi, Kuala Lumpur: Dewan Bahasa dan Pustaka.

Faruqi, Ismail Raji al-, 1982. Islamization of Knowledge: General Prinsiples And Workplan. Washington: International Institute of Islamic Thought (IIIT).

John Freely. Cahaya Dari Timur Peran Ilmuan Dan Sains Islam Dalam Membentuk Dunia Barat, terj. Noviatri, Jakarta: Penerbit PT Elexmedia Komputindo, t.t. 
Journal of Contemporary Islamic Studies

Justin McCarthy, The Ottoman Turks On Introductory History to 1923, London \& New York: Longman, 1997.

Kamarul Azmi Jasmi, Pendidikan Islam: Cabaran di Alaf baru dalam Seminar Pendidikan Islam, Madrasah Idrisiah Kuala Kangsar, 30 Oktober 2011. Lihat pautan, http://eprints.utm.my/41072/2/KamarulAzmiJasmi2011_ PendidikanIslamCabaranAlafBaru.pdf . Diakses pada 12/1/2017.

Kamus Dewan Edisi Keempat, 2007.

Lois A. Aroian \& Richard P. Mitchell, 1991. Timur Tengah Dan Afrika Utara Moden, terj. Mohammad Redzuan Othman, Kuala Lumpur: Dewan Bahasa dan Pustaka.

Mahmud Hamdi Zaqzuq, 1989. Orientalisme Kesan Pemikirannya Terhadap Tamadun Islam, terj. Mudasir Rosder \& Che Yusuf Che Mat, Kuala Lumpur: Dewan Bahasa dan Pustaka.

Mappanganro, 1989. Pemikiran Rasyid Ridha Tentang Pendidikan Formal Sebagai Terkandung Dalam al-Manar Dan Buku-Bukunya, Fakultas Pasca Sarjana IAIN Syarif Hidayatullah, Jakarta, (Tesis PhD, tidak diterbitkan).

Maryam Jameelah, 1983. Islam in Theory and Practice, Lahore: Mohammad Yusuf Khan and Sons,.

Mohamad Zaidin Mat, 2003. Bediuzzaman Said Nursi Sejarah Perjuangan Dan Pemikiran, Bangi: Jabatan Pengajian Arab Dan Tamadun Islam, UKM \& Sozler Nesriyat A.S.

Mohamad Zaidin Mat, 2001. Bediuzzaman Said Nursi Sejarah Pemikiran Dan Perjuangan, Malita Jaya: Selangor.

Mohd Kamal Hassan, 1988. Pendidikan Dan Pembangunan Satu Perspektif Bersepadu.

Mohd Nasir Ayub, 2015. Pemikiran Pendidikan Islam Menurut Badiuzzaman Said Nursi Dalam Risalah al-Nur, Bahagian Falsafah Dan Tamadun, 
Pusat Pengajian Ilmu Kemanusiaan, Universiti Sains Malaysia (Tesis $\mathrm{PhD}$, tidak diterbitkan).

Muhammad Quthb, 1985. Jahiliyah Abad Dua Puluh Mengapa Islam Dibenci, Bandung: Pustaka Mizan.

Muhammad Uthman al-Muhammdy, 2001. Pendidikan Islam Menurut al-Nadwi: Satu Analisis dalam Abu Hasan Ali al-Nadwi Pemikiran \& Perjuangannya, peny. Md Sidin Ahmad Ishak, KL: ABIM.

Muhammad Zahid al-Mullazkirdi, 1983. al-'Ujjalah al-Muqtatifah min Aqlam al-Afadil al-'Ulama' wa al-Dakatirah fi hayat al-Imam al-Jalil al-Ustaz Badi ' al-Zaman Sa 'id al-Nursi, Beirut: Dar al-Afaq al-Jadidah.

N.S. Daniach, 1972. Oxford English-Arabic Dictionary of Current Usage, Oxford: Oxford University Press.

Nadawi, Sayyid Abu al-Hassan 'Ali, 1969. al-Nahwu al-Tarbiyyah alIslamiyyah al-Hurrah fi al-Hukumat wa al-Bilad al-Islamiyyah, Lucknow: Dar al-Irsyad.

Nordin Kardi, "Konsep Universiti Dan Aplikasinya di Malaysia" dalam Jurnal GJAT, Disember 2011, Vol 1, Issue 1.

Nursi, Badiuzzaman Said, 2011. Sirah Zatiyah, terj. Ihsan Qasim al-Salihi, cet. 2, kaherah: Dar al-Nayl li al-Tiba'ah wa al-Nasyr,.

Philip K. Hitti, 2005.History of The Arabs, terj. R. Cecep Lukman dan Dedi Slamet Riyadi, Jakarta: PT Serambi Ilmu Semesta,

Ruhi al-Ba'labaki, 1995. al-Mawrid Qamus 'Arabi Inglizi, cet. 7, Beirut: Dar al-'Ilm li al-Malayin.

Salihi, Ihsan Qasim al-, 2003. Said Nursi: Pemikir Besar Abad ke 20, terj. Nabilah Lubis, Jakarta: Penerbit PT RajaGrafindo.

Sarwat Saulat, 1981. Said Nursi, Karachi: International Islamic Publishers. 
Journal of Contemporary Islamic Studies

Seyyed Hossein Nasr,1992. "Kata Pengantar" dalam Osman Bakar, Classification of Knowledge In Islam. Kuala Lumpur: Institut Kajian Dasar.

Sidek baba, 2003. "Globalisasi Dan Cabaran Pendidikan Islam" dalam Memahami Isu-Isu Pendidikan Islam di Malaysia, Suzalie Mohamad, Kuala Lumpur: Institut Kefahaman Islam Malaysia (IKIM).

Sidek Baba, 2009. Fikir Dan Zikir, Kuala Lumpur: Dewan Bahasa dan Pustaka.

Sukran Vahide, "Chronology of Said Nursi's Life" in Islam at The Crossroads: On the Life and Thought of Badiuzzaman Said Nursi, ed. Ibrahim M. Abu Rabi', Albany: State University of New York Press, 2003.

Sukran Vahide, 1992. Bediuzzaman Said Nursi The Author of the Risale-i Nur, Istanbul: Sozler Publication,.

Syed Muhammad al-Naquib al-Attas,1984. Konsep Pendidikan Dalam Islam, Bandung: Penerbit Mizan,.

Syed Muhammad Naquib al-Attas, 1992. Tujuan Dan Objektif Pendidikan Islam, terj. Samsudin Jaafar, Kuala Lumpur: Dewan Bahasa dan Pustaka,

Syed Sajjad Husain \& Syed Ali Ashraf, 1989. Krisis Dalam Pendidikan Islam, terj. Mas'ood Abdul Rasyid, Kuala Lumpur: Dewan Bahasa dan Pustaka.

The Pen, issue 15, 14/9/2012. Educational Reform Centring on Madrasatu'zZahra. Lihat laman http://www.thepenmagazine.net/educationalreform-centring-on-madrasatuz-zahra/. Diakses pada 13/2/2014.

Tibawi A.L., 1972. Islamic Education Its Traditions and Modernization into the Arab National Systems, London: Lucaz \& Company Ltd..

Monroe W.S, 1985. Turkey and The Turks, London: Darf Publishers Limited. 
Wa'il 'Abd al-Rahman al-Tall, 2008. Muqaddimah fi Usul al-Tarbiyyah, 'Amman: Dar al-Janadriyah li al-Nasyr wa al-Tawzi'.

Wan Jaffree Wan Sulaiman, 1987. Mujaddid Islam Bediuzzaman Said Nursi, Shah Alam: Penerbitan Hizbi.

Waqf Ikhlas Publications No. 6. The Religion Reformers in Islam, Istanbul: Hakikat Kitabevi, 1986.

Qaradhawi, Yusuf al, 2002. Kepincangan Umat Islam Masalah dan Penyelesaian, terj. Mohd. Fakhruddin Abdul Mukti, Kuala Lumpur: Pustaka ALHAS (M) Sdn. Bhd.

Zaini Ujang, 2012. Akademia Baru Memartabatkan UTM berjenama Global 2012-2020, Skudai: UTM..

Ziauddin Sardar, 2000. Merombak Pola Fikir Intelektual Muslim, terj. Agung Prihantoro \& Fuad Arif Fudyartanto, Yogjakarta: Pustaka Pelajar.

Zulkifli Haji Mohd Yusuf \& WM Ubaidillah WM Abas, 2011. "Menyanggah Pemikiran Barat Tentang al-Quran". 
